\title{
ГЕНДЕРНИЙ ДИСКУРС В ПСИХОЛОГІЧНІЙ НАУЦІ ТА ПЕДАГОГІЧНІЙ ПРАКТИЦІ
}

УдК: 305:159.922.8

\section{Говорун Т. В.}

Доктор психологічних наук, професор, професор Інституту педагогіки факультету права і суспільних наук у Сталевій Волі, Люблінський Католицький Університ ім. Яна Павла Другого, м. Люблін (Польща)

\section{Кікінежді О. $M$.}

Доктор психологічних наук, професор, завідувач кафедри психології, провідний науковий співробітник, директор науково-дослідного Центру з проблем тендерної освіти та виховання учнівської та студентської молоді НАПН Украӥни ТНПУ ім. В. Гнатюка, м. Київ (Украӥна)

\begin{abstract}
Анотація. $\quad$ С статті у гендерно-освітньому дискурсі представлено психологопедагогічні механізми конструювання гендерних орієнтацій у дітей та молоді на егалітарний чи традиційний (стереотипізований) характер статевих ролей, проведений контент-аналіз гендерних ідей освіти та виховання у навчально-виховному процесі. 3'ясовано, щзо сповідуванні прихильниками роздільного статевого виховання настанови суперечать засадам гуманістичної психолого-педагогічної спадщуини, призводять до насадження традиційних гендерних орієнтацій. Виявлено, щуо «тендерна матрищя» украӥнської педагогічної думки є підгрунтям для сучасних стандартів рівноиінності статей, розширення егалітарного світогляду батьків та педагогів, формування тендерної компетентності майбутніх вчителів та гендерної культури у підростаючого покоління.
\end{abstract}

Ключові слова: тендер, тендерне виховання та освіта, гендерний дискурс, традиційна та егалітарна культура, гендерна ідеологія.

\section{Постановка проблеми. Гендерна} (паритетна) демократія важлива не лише для міжнародного визнання, але і для внутрішньої динаміки нашої країни, для реалізації базових соціальних програм, зокрема для підвищення соціально-економічного статусу жінок, підви- щення їх частки в бізнесі, політикумі, залучення дівчат до освоєння професій, які є високо оплачуваними, тобто до наук точних, інженерних, попередження торгівлі людей, подолання сексизму в рекламі, викорінення нерівності між статями та забезпечення партнерст- 
ва між ними як прояву соціальної справедливості, забезпечення дієвих механізмів захисту від дискримінації за ознакою статі тощо.

Гендерне виховання залишається викликом часу і не менше, ніж раніше, потребує реальних змін в масовій та індивідуальній свідомості, в соціогуманітарному знанні, зокрема ідеології навчання і виховання школи, 3MI, розробки інноваційних гендерно-освітніх технологій відповідно до чинних нормативноправових документів України, міжнародних та національних стандартів якості життя та освіти (стаття 24 Конституції України, Закони України «Про освіту», «Про забезпечення рівних прав та можливостей чоловіків та жінок» (5.09.2005), «Концепція середньої загальноосвітньої школи України» (2016), «Біла книга Ради Європи з міжкультурного діалогу» «Жити разом у рівності та гідності», 2008, «Біла книга національної освіти України», 2010). Сьогодні не можна якісно підготувати сучасного педагога без вивчення ним гендерної теорії, що вже давно стало професійною нормою в демократичних країнах. На першочерговості цих завдань та їх реалізації наголошує президент Національної академії педагогічних наук України Василь Кремень: «Культура дитиноцентризму та інноваційності повинна визначати всю діяльність сучасного вчителя як у школі, так і поза іiі межами» [8, с. 412-413]. Мова йде не лише про визнання самоцінності дитинства, а про те, що особистісно-орієнтоване навчання і виховання у новій, розвивально-освітній парадигмі, передбачає системний підхід до гендерної соціалізації дитини як умови досягнення засад гуманізму та демократизму, формування гендерних компетентностей у всіх учасників соціокультурної взаємодії (освітян-науковців, батьків, вчителів, дітей) як ключових соціально-життєвих, що потребує певного рівня психологічної культури.

\section{Аналіз останніх досліджень i} публікацій. У контексті «генези здійснення особистості» (С. Максименко) сучасна психологія акцентує увагу на розвитку індивіда в системі процесів самопобудови і самоздійснення, гармонізації його внутрішнього світу із зовнішнім в умовах соціокультурної різноманітності, що спричинено глобалізаційними тенденціями На нашу думку, найвиразніше цей феномен репрезентується в межах гуманістичного та феноменологічного підходів, що дає змогу розкрити питання розвитку суб'єктності, самовираження, набуття «сутнісного Я» в суперечностях життя (Г. Балл, М. Боришевський,
В. Васютинський
I. Кон,
А. Маслоу,

В. Роменець, К. Роджерс, С. Рубінштейн, В. Татенко, Т. Титаренко та ін. учені). Стрижнем нового методологічного підходу у національній психології утворює ідея суб'єктності людини, 3 якою пов'язана самодетермінація іiі буття в світі, авторська позиція щодо подій життя, що дає змогу привернути увагу вчених до проблеми самовизначення індивіда у сфері традиційної та егалітарної культур. 
Гендер у вітчизняній педагогічній спадщині - це означення рівної участі статей у навчально-виховному процесі, в підготовці до виконання соціальних ролей у сім'ї та суспільстві, рівних можливостей дівчаток і хлопчиків для досягнення успіхів у майбутній життєдіяльності. Гендерна педагогіка в контексті гуманістичного підходу - це сукупність знань та методичних підходів, спрямованих на ознайомлення із засадами гендерного виховання, яке має нівелювати вплив патріархальних стереотипів на користь індивідуального шляху розвитку особистості (I. Бех, В. Кравець, А. Макаренко, В. Сухомлинський, С. Русова, К. Ушинський та ін.). Важливими пріоритетами у розробці дієвих гендерних програм, поряд із врахуванням міжнародного досвіду, $є$ «ідеологія самовизначення» молоді (В. Кремень), збереження «ідентичності української освіти як сердечної, духовної і душевної, людської і людяної, народної і родинної, патріотичної і моральної у Bcix загальнолюдських вимі-

рах» (В. Андрущенко).

Саме на вчителя в першу чергу покладена головна місія розвитку ідеології рівних прав і можливостей і прав статей (егалітарних гендерних орієнтацій) для досягнення будьяких життєвих цілей та індивідуального розвитку, не обмеженого статевою належністю, 3 метою побудови суспільства паритетної демократії як асиміляції парадигми «єдиної спільноти рівноправних людей». Проте шлях до гендерної культури пролягає як через гендер- ну поінформованість (обізнаність), так і гендерну чуйність (уміння толерантно ставитись до рівня наукових знань, усвідомлення проблеми, стереотипізації свідомості) і, навіть, мотивації небажання чи навіть свідомого її спрямування в протилежному напрямку.

Якою мірою гендерні знання стали надбанням психологічних досліджень та педагогічної практики? Чи дотримується сучасна школа основних їі засад?

Мета статті. В статті була поставлена мета проаналізувати найбільш виразні прояви гендерних орієнтацій, які декларуються офіційною позицією Міністерства науки і освіти України та реальними гендерними практиками, поширеними на педагогічній ниві України. Завдання статті - застосування контент аналізу щодо головних ідей, сповідуваних у висвітленні провідними мас-медіа наукових та прикладних аспектів гендерного виховання та навчання, висвітлення плюсів та мінусів цього процесу та показати позитивний досвід поширення егалітарних гендерних настанов.

Нами була висловлена гіпотеза про те, що плюралізм поглядів в демократичному виборі країни прихильники патріархальної російської сім’ї використовують для насадження традиційних гендерних орієнтацій в сфері освіти та виховання школярів. Сповідувані прихильниками роздільного статевого виховання виховні настанови суперечать класич- 
ному надбанню гуманістичної психологічної та педагогічної наук.

Виклад основного матеріалів і peзультатів дослідження. Посилаючись на наукові розробки проблеми формування гендерної культури дітей та молоді, здійснені вітчизняними вченими у теоретичних та експериментальних підходах до означеної проблеми, ми виходимо 3 положення про соціальнокультурне наслідування статевих стереотипів, нормативних очікувань статеворольової поведінки, засвоєння індивідом сімейних та публічних ролей. Гендер як соціально-психологічна характеристика статі особистості виступає тим найважливішим культурним знаком, яким людина оволодіває вже в перші роки свого життя. При цьому розрізняють два рівні творення гендера: на рівні культури та індивідуальної свідомості, що є відображенням соціокультурного характеру інтеракцій між людиною і соціумом 3 точки зору усвідомленого прийняття та відтворення нею гендерних традиційних чи егалітарних цінностей.

Гендерний підхід як ексклюзивна теорія та методологія на сьогоднішній день досить органічно увійшла у психологічну науку, оскільки гендерно-орієнтовані дослідження містять цінну інформацію, що забезпечує розуміння загальних і специфічних закономірностей особистісного розвитку представників жіночої та чоловічої статі. У різних країнах він має різну назву: гендерний аналіз, «гендерні лінзи», гендерний вимір, гендерна інтеграція тощо. Завданням гендерного дискурсу є збір та оцінка статево-диференційованої інформації щодо різних аспектів приватного i суспільного життя чоловіків і жінок. Перспективними в цьому плані є дослідження механізмів соціального пізнання на основі категорії гендеру в контексті психологічних концепцій С. Бем, крізь призму теорій гендерних схем і лінз гендера, а саме: лінз гендерної поляризації, андроцентризму та біологічного есенціалізму. Спільним висновком численних зарубіжних і вітчизняних досліджень $є$ те, що психологічні відмінності в межах однієї статі можуть бути більшими, ніж між статями $[2 ; 4 ; 6$; $7 ; 11 ; 12]$.

Гендерні дослідження переконливо показали, що традиційні настанови представлені біполярністю фемінних та маскулінних властивостей, а значить і протиставленням жіночого і чоловічого у виконанні соціальних, сімейних та суспільних ролей. На противагу традиційній, патріархальній андрогінна концепція, яка побудована на поєднанні «чоловічих» i «жіночих» властивостей, їх високому розвитку і прояву залежно від ситуації, передбачає універсалізацію сімейних, професійних та громадсько-політичних ролей, їх взаємозамінність в сімейному функціонуванHi.

Ідеї суб'єктності як здатності до саморефлексії власних властивостей і вчинків, набутої когерентності власних ціннісносмислових настанов психологи 
М. Боришевський [3], В. Татенко [9] вважають необхідними в самореалізації, самовиявленні особистості, а також в розгортанні їі сутнісних сил, що є необхідною умовою досягнення щастя як для жінок, так і чоловіків. Ці теоретичні положення виявились продуктивними в розумінні повноти розгортання сутнісних сил індивіда, творчого потенціалу незалежно від статевої належності. Гендерна культура розглядається як система соціально-економічних, правових та етнопсихологічних умов існування суспільства, що сприяє становленню чоловіка та жінки як різних біологічно, проте соціально рівноцінних особистостей. У психологічному вимірі особливого значення набуває зміст цінностей, що культивуються у гендерному освітньому дискурсі, орієнтація на егалітарний характер статевих ролей, який забезпечує їх універсалізацію та взаємозамінність.

Гендерна субкультура суспільства - це сфера ідеології макросистеми. Традиції, звичаї, ментальність народу, взаємодія різних субкультур можуть нести в собі різні гендерні настановлення - як егалітаризм, так і сексизм, дискримінацію за статтю. Патріархальна (традиційна) дискурсивна конфігурація поділяє сфери діяльності, суспільні та сімейні ролі на чоловічі та жіночі, як відповідно домінуючі i підлеглі. Егалітарна (демократична) пропагує рівність та взаємозамінність у різних сферах діяльності чоловіків та жінок як рівноцінних особистостей.
Сучасний етап розвитку українського суспільства спричиняє амбівалентне ставлення до системи гендерних ролей, конфлікт між давнім дихотомічним їх розподілом та новими, егалітарними викликами до них, що свідчить про серйозність ситуації та необхідність зміцнення державної гендерної політики, іii інформаційної та освітньої складової.

Чи розуміють сучасні педагоги, працівники 3МI, на які взірці гендерної поведінки слід орієнтуватись і які досягнення повинні пропагуватись як новаторські у виховному процесі та соціалізації особистості? Якими є суспільні індикатори гендерного розвитку особистості?

Останнім часом спостерігаються спроби ренесансу патріархату - пропаганди статеводиференційованого навчання та виховання дітей, насадження стереотипу «втрати жіночності» дівчатами, які починають освоювати статевонетипові професії, зокрема, військовослужбовців чи менеджерів тощо. Продовжується активізація так званих громадськопедагогічних рухів на зразок «батьківських комітетів», які сприймають запровадження гендерної освіти як «підрив національної ментальності», замах на моральні засади сім’ї та звинувачують освітян в насадженні гомосексуальної поведінки. Головною тезою виступає ідея поділу світу на «чоловіче» і «жіноче», «сильну» і «слабку» стать, на раціональне і емоціональне, мовляв, психологічні властивості статей різні і навіть полярні, тож гендерне 
виховання суперечить природному призначенню статей і повинно ігноруватись. Протиставлення соціалізації статей походить від перенесення анатомічних відмінностей на диференціацію соціальних ролей і обов'язків статей i виховання відповідних психічних властивостей.

Популярні мас медіа у різний спосіб експлуатують ідею полярності інтересів, уподобань, нормативів поведінки статей, що формує у дітей та молоді хибні життєві настанови, на зразок, приваблива зовнішність - запорука успіху жінки, то ж молодість та красу варто продати якнайдорожче. Фінансовий статус вважають мірилом оцінки чоловічої статі, оскільки її призначення - бути годувальником i захисником, то ж сфера інтересів «справжнього» чоловіка завжди поза домом, в соціумі. У цьому ракурсі значний інтерес представляє розгляд гендеризації суспільного життя Іриною Грабовською, яка слушно зауважує, що: гендерний розвиток суспільства $\epsilon$ умовою його поступу, а не лише результатом; сьогодні настає час для серйозної аналітичної і практичної роботи по адаптації європейського досвіду до реалій українського суспільства; потрібно орієнтуватись на інтелектуальне середовище і працювати насамперед зі студентською молоддю, пошук «золотої середини» в питаннях гендерної просвіти населення, врахування передусім принципів гендерного мейнстримінгу [5].

Багаторічний досвід дослідження ген- дерних проблем та ознайомлення із досвідом зарубіжних країн дав можливість сформувати власне бачення щодо подальшої інституалізації гендерно-освітніх механізмів у національну школу. Слід зазначити, що сучасні педагогічні журнали та педагогічна преса нерідко пропагандують ідеї «організації груп окремого навчання та виховання дітей», «забезпечення рівня знань, практичних умінь та навичок відповідно до статі». У змісті сценаріїв та методичних рекомендацій, будь-то ігри для пальчикового театру чи інсценування живих картинок, головні дійові особи, як правило, чоловічої статі. Як і в дитячій літературі чи журналах, вони змагаються, вирішують проблемні життєві ситуації, ремонтують, майструють, ведуть за собою тощо, в той час як жіночі персонажі залишаються пасивними у громадських справах, очікуючими на допомогу з боку «сильної» статі. Наприклад, апофеозом гендерного виховання $\epsilon$ рекомендації щодо «дівчачої» і «хлопчачої» половини у дитсадку, де для дівчаток - вітальня з мініатюрними м'якими меблями, міні-кафе з вазочками, святковий стіл з багатством страв, виліплених $з$ тіста, шафа 3 косметичними флакончиками, наряди... А що ж хлопчики? Виявляється, вони після знайомства зі світом дівчаток з полегшенням повертаються на свою половину, до своїх сабель, пожежних шоломів і солдатиків ...».

Нами проведений контент-аналіз гендерних ідей освіти та виховання, що пропагувались в передачах на свята освітян - 1 Вересня, День вчителя на провідних телевізійних кана- 
лах. Наведемо один з прикладів, занотованих нами: "Чи задумувались ви над тим, як із маленької донечки виростити справжню, впевнену в собі панянку: освічену, розумну, чемну, приємну в спілкуванні, майбутню берегиню родинного тепла? Це дійсно дуже нелегка справа. Але шлях здійснення мрії відкривають двері ліцею-інтернату «Кадетський корпус» (класи паняночок). Крім загальноосвітньої програми панянки поглиблено вивчають англійську мову, займаються хореографією, образотворчим мистецтвом, бісероплетінням, відвідують театральну студію, уроки вокалу, хоровий спів, вивчають правила етикету, пізнають основи християнської моралі. Гасло виховання ліцею «істинних леді»: «Мати мир 3 усіма і бути гарною щодня!».

Якою має бути сучасна дівчина згідно настанов ліцею?: «Розумною, з розвиненими інтелектуальними здібностями, ерудованою, пунктуальною, яка навчається цінувати свій час». «Бути доглянутою в усіх відношеннях, від зачіски, до черевичків, яка вміє володіти собою і своєю мовою, бути сучасною, значить бути жіночною». «Паняночка повинна знати, в чому секрет іiї чарівності, вона вміє підкреслити свою родзинку і приховати недоліки».

Ось які гендерні настанови комерційного освітнього закладу, який виховує «справжнісіньких леді», занотовані нами як інтеріоризовані паняночками цього закладу: «Мальчишки вредные, а девочки только иногда»; «Панянки опановують мистецтво гостин- ності (как держать осанку, вилку, нож); Панянка: «умная», «терпеливая», «воспитанная, как богиня, грациозная, как принцесса», «чистенькая», «следит за собой», «никогда не ругается», «образец доброты, ума и вежливости», «Должна быть ангелом...».

Вимогою часу, на наш погляд, стало нове прочитання і нове розуміння педагогічного досвіду видатних гуманістів-педагогів, що дає відповідь на багато запитань, які ставляться у загальноосвітніх закладах стосовно гендерного виховання хлопчиків та дівчаток, принципів гендерної рівності у вихованні обох статей сучасними «новаторами». Що міг би відповісти Антон Макаренко прихильникам роздільного виховання: «У нас, як і будь-якій здоровій сім'ї, живуть разом дівчатка і хлопчики, і це не викликає жодних ускладнень. Будь-яка здорова дитяча спільність може прекрасно розвиватись в цих умовах.... Стосунки між дівчатками і хлопчиками у нас виключно товариські» i продовжував: «Приблизно так міркували педологи, коли створювали окремі заклади для «важких», окремі для нормальних. Та й тепер грішать, коли окремо виховують дівчаток і хлопчиків...» [10, c. $416-417]$.

Можливо, сучасним «новаторам» доцільно було б познайомитись також $з$ думками Несторки української педагогічної літератури, як називали ії сучасники, Софії Русової, яка дискутувала з проблеми спільного навчання дівчаток $\mathrm{i}$ хлопчиків 3 відомим американським психологом Стенлі Холлом: «Коли з дитинства дітей 
ведуть спільно - і дівчата і хлопці у спільній праці і спільних іграх і розвагах звикають до товаришування, тоді в юнацькому віці це товариство не стає для них чимось незвичайним, і по всіх школах, де коедукація поставлена 3 великою увагою взагалі до психології учнів, там вона дає найкращі наслідки - зближує обидві статі, паралізуючи небажаний флірт справжніми товариськими відносинами, ставлячи ці взаємини на певний шлях спільної праці, прагненнями до одної загальної мети, товариського інтимного догляду вихованців та виховниці». I це підтверджують ухвали батьків, вихователів і самих учнів у тих школах, де коедукація вже введена. Але, дійсно, вона вимагає певних умов для плодотворної іiі реалізації. Вона потребує передусім: 1) свідомих вихователів, відданих своїй праці, вихователів, що розуміють психіку своїх учнів і учениць; знавців гігієни цього періоду i тактовних у своїх відносинах до учнів; вихователів, що мають довір'я до учнів; 2) виховання і навчання у школах для обох статей обов'язково треба проводити $з$ уважливою індивідуалізацією, щоб не перевантажувати дівчат, коли вони нездужають чи виявляють такі нахили, які не завше у згоді з програмою школи; 3) треба, щоб батьки в родинному житті додержувалися тих же принципів, якими керується школа, установлюючи відносини між учнями взагалі, не поділяючи їх різко на хлопців та дівчат і ставлячи до них однакові вимоги, що відповідають їх фізичним та інтелектуальним силам. Бажано, щоб і найближче громадянство ставилося до коедука- ції можливо з більшим розумінням справи $\mathrm{i}$ співчуття до неї» [13, с. 288].

«Гендерна матриця» української педагогічної думки є підгрунтям для сучасних стандартів рівноцінності статей, розширення егалітарного світогляду батьків та педагогів, створення позитивної моделі навчання та виховання дівчаток і хлопчиків. Перечитуючи твори Василя Сухомлинського, написані тоді, коли гендерна проблематика ще не була предметом наукових досліджень і навіть термін «тендер» ще не був у вжитку, можна дивуватися прозорливості його поглядів щодо проблеми рівності статей, які воістину випередили час. Його гуманістичні настановлення щодо статевого виховання підлітків та юнацтва, формування дитячих уявлень про мужність, жіночність, побудову педагогічного процесу на засадах рівності, егалітарності, подолання педагогами статевих стереотипів тощо залишаються найактуальнішими у вітчизняному педагогічному дискурсі нового тисячоліття.

Видатний педагог сформулював практичні рекомендації щодо розв'язання проблеми гендерної соціалізації, надзвичайно важливих для змісту егалітарного виховання, яке базується на неупередженому ставленні до особи, іï пошануванні незалежно від статевої належності: «Як вогню бійтеся, щоб дівчатка відчували: ми - слабші, наша доля - підкорятися» «Щоб уміти по-справжньому, по-чоловічому любити, треба бути людиною сильної волі. Це, звичайно, потрібно однаковою мірою й дівчинці, й хлоп- 
чикові...» $[14$, с. 350$]$. Чи не співзвучні ці слова педагога сучасній тезі гендерної педагогіки: «Дівчатка і хлопчики мають багато подібного i небагато відмінного?», «Різні, проте рівні?».

Не менш актуальними для розвитку гендерних орієнтацій педагогів, і не тільки для них, але й численної армії прибічників традиційного розподілу ролей, причетних до пропаганди тези: «Все в руках жінки», «Тільки Берегиня здатна підтримувати лад в сім’ї», «Якщо жінка буде мати змогу більше займатись дітьми та домом, то...», є думки Василя Сухомлинського щодо виховання дівчаток: «По-перше, треба, щоб кожна дівчинка виховувалась самобутньою і яскраво вираженою особистістю, щоб усім без винятку дівчаткам нестерпною була навіть думка лишатися непомітною, пасивною, слабовільною. Орієнтація дівчинки-жінки на активну участь у суспільному виробництві, а не на пасивну роль домашньої господарки, на пасивне обмеження сфери їі діяльності доглядом за дітьми - ось що дуже важливо в тому загальному тоні, який має характеризувати духовне життя школи. Бути матір'ю, бути вихователем дітей - горда й почесна місія, але коли тільки цим обмежиться діяльність жінки - вона буде залежною істотою. Тільки яскрава життєва мета дає жінці духовну силу, яка робить іiі володарем і повелителем у сфері почуттів» [15, с. 573].

Відповіддю на «новаторські» ідеї сучасної «педагогіки», а саме відкриття ліцеїв для роздільного навчання дівчаток і хлопчиків, як, наприклад, «школи для справжніх леді», де «слабку» стать починають виховувати як у «добрі дореволюційні часи» - щоб знала мови, етикет, пластику рухів, рукоділля і т.П., є звернення видатного педагога до вчителя: «Місія вихователя - допомогти кожній дівчинці знайти поле виявлення iї індивідуальних здібностей у багатогранній діяльності, пов'язаній 3 навчанням, щоб дівчинка переживала гордість дослідника, мислителя, творця. Щоб поруч із сумлінним старанним виконанням усіх навчальних завдань ішло багате інтелектуальне життя, виражене у творчості. У гуртках нашої школи - дівчатка виконують не другорядні, а провідні, творчі завдання... Чим багатше інтелектуальне життя колективу, тим яскравіше розкривається чоловік перед жінкою й жінка перед чоловіком передусім як людина з усім іiї багатством, а не як істота протилежної статі. Це дуже важливо для виховання справжніх жінок і справжніх чоловіків. Щоб полюбити дівчину як жінку, хлопець повинен здобути моральний досвід поваги іiї як обдарованої, самобутньої, мудрої, незалежної особистості» $[15$, с. 574]. Чи «Не повинно бути таких трудових взаємовідносин, щоб дівчатка обслуговували хлопчиків і звикали таким чином до ролі домогосподарки. Те, що треба робити в домашньому господарстві, однаково вміло й старанно повинні робити жінки і чоловіки. Коли і є який розподіл в самообслуговуванні, то він має бути тимчасовим: сьогодні хлопці виконують одну роботу, завтра - іншу» [15, c. 576].

Традиційна гендерна ідеологія побудова- 
на на дихотомії чоловічого та жіночого і на відповідній диференціації умінь та навичок, професійних здібностей тощо. Гендерний дискурс скеровує педагогів: «Треба так організувати діяльність колективу, щоб не було спеціально чоловічих і спеціально жіночих видів діяльності (це, однак, не означає, що й найважчу фізичну працю мають ділити хлопці й дівчата). «Мене ніколи не радує, що в окремих дівчаток занадто багато старанності, акуратності і мало ініціативності, самостійності, рішучості. У майбутньої матері треба виховувати громадянську стійкість, почуття власної гідності, а не безсловесну покірливість. Покірливість, вироблена одностороннім вихованням (це - дозволяється, це - забороняється), породжує ідейну безхребетність»; «Треба організувати колективну діяльність так, щоб живі справи дівчаток і хлопчиків були емоційно насичені, пробуджували в дівчаток яскраву моральну оцінку того, що їх оточує, що вони роблять. Гідність майбутньої жінки, матері, дружини формується тоді, коли вона одухотворена громадськими інтересами, турботами, хвилюваннями колективу»; «...Дівчатка мають жити активним громадянським життям, занадто велика зосередженість на самій собі, заглиблення в свій внутрішній духовний світ... призводить до того, що в роки ранньої юності дівчина стає беззахисною, коли треба відстояти свою честь і гідність»; ...«Не допустити того, щоб жінки наші ставали освіченими, інтелектуально багатими рабинями - одне з дуже важливих завдань школи» (В. Сухомлинський) [14, с. 350].
Можна сказати, що позиція українських педагогів-гуманістів не заперечує принципів гендерно чуйного виховання, що грунтується на врахуванні індивідуальних відмінностей та антропологічно зумовлених потенцій дитини як представника конкретної статі: «...відразу важко повірити, що дівчатка і хлопчики на своєму виробництві досягають такої кваліфікації. Стосовно дівчат потрібно внести поправку: вони так само швидко досягають стаханівських норм виробітку, тільки не у металообробному виробництві, а в процесі збору, монтування, у виробництві з легкою фізичною працею, особливо в оптичному виробництві: у виробництві лінз, де потрібно більше чистоти і точності; вони переганяли хлопців у точних рухах та увазі. Хлопці переважали своїми здібностями конструкторів, а дівчата - своїми здібностями до точності, організованості у важких та відповідальних процеcax. Хлопчики не могли справитися з виробництвом лінз, і все це виробництво передали дівчаткам» (А. Макаренко) [10, с. 96].

Унікальність «гендерної матриці» української педагогічної спадщини полягає у створенні культуротворчого соціуму для розвитку ідей сучасного гендерного виховання в мультикультурному середовищі, виховання гендерної обізнаності, чуйності та толерантності Право бути собою, робити вільний та свідомий вибір, андрогінність як інтеграція «жіночого» $\mathrm{i}$ «чоловічого» в одній особі, максимум можливостей для особистісного розвитку, партнерство статей тощо складає суть педагогічного дискур- 
су на шляху до інтеграції в європейський освітній простір.

Співзвучною практиці особистісноорієнтованого та гендерно-чутливого підходів в освіті, що виходить із демократичної моделі суспільства як спільноти рівноправних індивідуальностей, $є$ саме егалітарна соціалізація, яка на сьогодні визнається найбільш прогресивною та продуктивною. Гендерно-чутливий підхід передбачає розширення соціалізуючого середовища для обох статей: доповнення зон самореалізації дітей (наприклад, заохочення дівчаток до занять спортом, а хлопчиків - до самообслуговування); організація досвіду рівноправного співробітництва дівчаток і хлопчиків у спільній діяльності; зняття традиційних культурних заборон на емоційне самовираження хлопчиків, заохочення їх до вираження почуттів; створення $з$ дівчатками досвіду самозаохочення й підвищення самооцінки (наприклад, технологія щоденника 3 фіксуванням успіхів); створення умов для тренування міжстатевої чутливості (наприклад, через театралізацію, обмін ролями); залучення татів (а не лише матерів) до виховання дітей. Навчити вихованця керуватись певними демократичними нормативами в оцінці взаємин статей неможливо шляхом механічного переадресування тієї чи іншої інформації гендерного характеру. Вона потребує особистісного переосмислення з позиції ідентифікації «сократівського» аналізу сформованих переконань: «Як можна поглянути на проблему з іншого боку, з позиції іншої статі?» У цьому процесі напрацювання когнітивної психологічної школи, досвід когнітивного консультування відіграють провідну роль. Ось чому особистісний, індивідуальний підхід до учнів, застосування інтерактивних форм навчання, діалогічне спілкування розглядаються наріжним каменем гендерно-освітніх технологій. У цьому контексті важливе значення має проведення просвітницько-інформаційної та практичної роботи, спрямованої на теоретичне та прикладне вирішення гостроактуальних проблем 3 гендерного виховання.

Висновки. Питання статевого виховання були, є і будуть вічними в освіті та вихованні людини. До запровадження в 60-х роках минулого століття терміну «гендер» як більш влучного для відокремлення його від слова стать, поняття статевої, статеворольової поведінки було і залишається органічною складовою будь-якої педагогічної теорії.

- Поняття гендер як характеристика соціального становища хлопчиків та дівчаток, чоловіків та жінок не є окремим напрямом в педагогіці, воно опосередковує всі сфери життєдіяльності людини (як приватну, так і професійну, громадську) впродовж всього циклу іiі життя.

- Найбільш співзвучними нашому часові й перспективам формування гендерної культури у дітей та молоді $є$ оновлення традицій та впровадження інновацій в контексті спадщини видатних українських педагогів-гуманістів Г. Ващенка, М. Драгоманова, А. Макаренка, 
С. Русової, В. Сухомлинського, К. Ушинського та ін. учених.

- Ознайомлення 3 педагогікою та психологією гендерного виховання журналістів, учителів, керівників освітніх закладів, активізація діяльності кафедр гендерної просвіти у всіх педагогічних університетах та інститутах, впровадження гендерної просвіти в навчально -виховний процес середніх загальноосвітніх шкіл та ліцеїв є нагальним організаційним завданням.

- Пропагування положень гуманістичної педагогічної спадщини, прийняття та дотримання вчителем, вихователем, адміністратором освіти, батьками учнів засад гендерної педагогіки сприятиме вирівнюванню позиції статей в освоєнні тих чи інших видів діяльності, будь-то професійна освіта, галузь працевлаштування, громадсько-політична активність.

Перспективи подальших досліджень полягають у розробці та впровадженні гендерно-освітніх інноваційних технологій задля прогностики вирівнювання можливостей самореалізації молодого покоління для побудови егалітарної моделі статевої соціалізації.

\section{Перелік використаних джерел:}

1. Балл Г.А. Психология в рациогуманист ической перспективе. - К. : Основа, 2006. - 408 с.

2. Бем С. Линзы гендера: Трансформация взглядов на проблему неравенства полов / [пер. с англ.]. - М. : «Российская политическая энциклопедия» (РОССПЭН), 2004. -336 c.
3. Боришевський М. Й. Дорога до себе: від основ суб'єктності до вершин духовності : монографія. - К. : Академвидав, 2010. - 416 с.

4. Говорун Т. В. Гендерна психологія : навч. пос. для студ. вищ. навч. закл. / Т. В. Говорун, О. М. Кікінежді. - К. : Видавничий центр «Академія», 2004. - 308 с.

5. Грабовська I. Українські реалії гендеризації [Електронний ресурс] . - Поликантроп. 2014. - Режим доступу : http://politikan.com.ua/0/0/0/86890.htm

6. Кіммель М. Гендероване суспільст во. - К. : Сфера, 2003. $-490 \mathrm{c}$.

7. Кравещь В. П. Гендерна педагогіка : навч. пос. для студ. вищ. педагог. закл. освіти. - Тернопіль : Джура, 2003. $-416 \mathrm{c}$.

8. Кремень В. Г. Філософія людиноцент ризму в ст ратегіях освітнього простору. - К. : Педагогічна думка, 2009. $-520 \mathrm{c}$.

9. Людина. Суб'єкт. Вчинок: Філософсько-психологічні студії / [за заг. ред. В. О. Татенка]. - К. : Либідь, 2006. $360 \mathrm{c}$.

10. Макаренко A. C. Педагогічні т вори : у 8 т. Т. 5 : Книга для батьків. - М. : Педагогіка, 1986. - 336 с.

11. Максименко С. Д. Генеза здійснення особистості. К. : TOB «КМM», 2006. - 240 c.

12. Основи т еорії гендеру : посібник / ред. колегія В. П. Агеєва, Л. С. Кобелянська, М. М. Скорик .- К. : K.I.C., 2004. - 535 c.

13. Русова С. Ф. Вибрані педагогічні т вори : у 2 кн. Кн. 2. - К. : Либідь, 1997. - 318 с.

14. Сухомлинський В. О. Вибрані т вори : у 5 т. Т. 1 : Проблема виховання всебічно розвиненої особистості. - К. : Радянська школа, 1977. - 672 с.

15. Сухомлинський В. О. Вибрані т вори : у 5 т. Т. 3 : Серце віддаю дітям. - К. : Радянська школа, 1977. - 670 с.

16. Як навчат и школярів долат и гендерні ст ереот ипи: конспекти занять : навч.-метод. пос. для загальноосвітніх навч. закл. / [Т. Говорун, О. Кікінежді, В. Бондаровська та ін.] ; за заг. ред. проф. Т. Говорун. К. : ТОВ «Дорадо-Друк», 2011. - 804 с. 


\section{References (Transliteration):}

1.Ball G. A. Psihologiya v ratsiogumanisticheskoy perspektive. - K. : Osnova, 2006. -408 s.

2. Bem S. Linzyi gendera: Transformatsiya vzglyadov na problemu neravenstva polov / S. Bem ; [per. s angl.]. - M. : «Rossiyskaya politicheskaya entsiklopediya» (ROSSPEN), 2004. - 336 s.

3. Borishevskiy M. $Y$. Doroga do sebe: vId osnov sub'EktnostI do vershin duhovnostI : monograflya. - K. : Akademvidav, 2010. - $416 \mathrm{~s}$.

4. Govorun T. V. Genderna psihologIya : navch. pos. dlya stud. visch. navch. zakl. / T. V. Govorun, O. M. KIkInezhdI. - K. : Vidavnichiy tsentr «AkademIya», 2004. $-308 \mathrm{~s}$.

5. Grabovska I. UkraYinskI realIYi GenderizatsIYi [Elektronniy resurs]. - Polikantrop. 2014. - Rezhim dostupu : http://politikan.com.ua/0/0/0/86890.htm

6. KImmel M. Genderovane suspIlstvo. - K. : Sfera, 2003. $-490 \mathrm{~s}$.

7. Kravets $V$. P. Genderna pedagogIka : navch. pos. dlya stud. visch. pedagog. zakl. osvIti. - TernopIl : Dzhura, 2003. $-416 \mathrm{~s}$.

8. Kremen V. G. FIlosoflya lyudinotsentrizmu v strategIyah osvitnogo prostoru. - K. : PedagogIchna dumka, 2009. $520 \mathrm{~s}$.

9. Lyudina. Sub'Ekt. Vchinok: FIlosofsko-psihologIchnI studIYi / [za zag. red. V. O. Tatenka]. - K. : LibId, 2006. $360 \mathrm{~s}$.

10. Makarenko A. S. PedagogIchnI tvori : u 8 t. T. 5 : Kniga dlya batkIv. - M. : PedagogIka, 1986. - 336 s.

11. Maksimenko S. D. Geneza zdIysnennya osobistostI / S.

D. Maksimenko. - K. : TOV «KMM», 2006. - $240 \mathrm{~s}$.

12. Osnovi teorIYi Genderu : posIbnik / red. kolegIya V. P. AgeEva, L. S. Kobelyanska, M. M. Skorik . - K. : K.I.S., 2004. $-535 \mathrm{~s}$.

13. Rusova S. F. VibranI pedagogIchnI tvori : u 2 kn. Kn. 2. - K. : LibId, 1997. - 318 s.

14. Suhomlinskiy V. O. VibranI tvori : u 5 t. T. 1 : Problema vihovannya vsebIchno rozvinenoYi osobistostI. $-\mathrm{K}$. :
Radyanska shkola, 1977. - 672 s.

15. Suhomlinskiy V. O. VibranI tvori : u 5 t. T. 3 : Sertse vIddayu dItyam. - K. : Radyanska shkola, 1977. - $670 \mathrm{~s}$.

16. Yak navchati shkolyarIv dolati GendernI stereotipi: konspekti zanyat : navch.-metod. pos. dlya zagalnoosvItnIh navch. zakl. / [T. Govorun, O. KIkInezhdI, V. Bondarovska ta In.] ; za zag. red. prof. T. Govorun. - K. : TOV «DoradoDruk», 2011. - 804 s.

\section{Hovorun Tamara}

Doctor of Psychology, professor of the Pedagogy Institute at The Department of Law and Social Sciences in Stalewa Wolia, John Paul the II Catholic University, Stalewa Wolia (Poland)

\section{Kikinezhdi Olga}

PhD, Doctor of Psychology, professor, Head of the Psychology Department at Ternopil Volodymyr Hnatiuk National Pedagogical University, Ternopil (Ukraine)

\section{GENDER DISCOURSE IN THE PSYCHO- LOGICAL SCIENCE AND PEDAGOGICAL PRACTICE}

\section{ABSTRACT}

Reaching in the parity of articles as a strategic direction of gender socialization of children and youth involves identifying the socialpsychological factors in the formation of gender culture of young people, need to study the internal mechanisms of the individual identification of certain sex-role models behavior, approval of egalitarian values. The current stage of development of Ukrainian society causes ambivalent attitude to the system of gender roles, the conflict between the old dichotomy of distribution and new, an egalitarian challenge to them, which indi- 
cates the seriousness of the situation and the need to strengthen the state gender policy, its information and education component.

Recently, observed attempts to Renaissance patriarchy - propagation of the sexdifferentiation education and parenting of children, planting stereotype of «loss of femininity» girls who begin to develop gender atypical occupations. Continuing activation of socialpedagogical movements like «parent councils» who perceive the introduction of gender education as «undermining national mentality» attempt on the moral principles of the family and educators accused of planting homosexual behavior. It was found that professed supporters of separate of sex education instruction contradict to the principles of humanistic psychology-pedagogical heritage, lead to the traditional stereotyped patterns of socialization.

Found that «gender matrix» Ukrainian educational thought is the basis for modern standards of equivalence gender of human expansion of an egalitarian worldview of parents and teachers, the formation of gender competence of future teachers and gender culture in the younger generation. The introduction of gender education in the educational process of schools, colleges, and universities are the urgent organizational tasks. Right to be yourself, to make free and informed choices, androgyny as the integration of «Women» and «men» in one person, maximum opportunities for personal development, partnership etc., is the essence of psychological- pedagogical discourse towards to European integration.

Keywords: gender, gender upbringing and education, gender discourse, traditional and egalitarian culture, gender ideology.

\section{Говорун Тамара Василевна}

Доктор психологических наук, профессор, профессор Института педагогики факультета права и соичильньхх наук в Сталева Воля, Католического Университета имени Иоанна Павла II, Сталева Воля (Польша)

\section{Кикинеджн Оксана Михайловна}

Доктор психологических наук, профессор, заведующий кафедрой психологии, ведущиий научный сотрудник, директор научно-исследовательского Центра по проблемам гендерного образования и воспитания учащейся и студенческой молодежи НАПН Украинь -ТНПУ им. В. Гнатюка (Украина)

\section{ГЕНДЕРНЫЙ ДИСКУРС В ПСИХОЛОГИЧЕСКОЙ НАУКЕ И ПРАКТИКЕ}

\section{Аннотация. В статье в гендерно-} образовательном дискурсе представлены психолого-педагогические механизмы констуирования гендерных ориентаций у детей и молодежи на эгалитарный или традиционный (стереотипизированный) характер половых ролей, проведен контент-анализ гендерных идей образования и воспитания в учебновоспитательном процессе. Установлено, что взгляды и установки сторонников раздельного полового воспитания противоречат гуманистическому психолого-педагогическому наследию, приводят к насаждению традици- 
онных гендерных ориентаций. Выявлено, что «гендерная матрица» украинской педагогической мысли является основой для современных стандартов равноценности полов, расширения эгалитарного мировоззрения педагогов и родителей, формирования гендерной компетентности у будущих учителей и гендерной культуры у подрастающего поколения.

Ключевые слова: гендер, гендерное воспитание и образование, гендерный дискурс, традиционанная и эгалитарная культуpa, гендерная идеология. 